\title{
12
}

\section{Introduction: International Organisations and Transnational Diffusion}

\section{Kerstin Martens and Dennis Niemann}

For many years, almost all fields of social policy have been considered an exclusively national domain. The international level used to play only a minor role when it came to matters of healthcare, pensions, social protection, education policies and the like. In many social policy fields, supranational problems did not manifest to such an extent that international solutions were needed. Furthermore, changes in a social policy field in one country did not have direct consequences for that field in other countries. The welfare state was only affected by international developments insofar as they constituted a problem that spilled over into the national sphere. In addition, international institutions, such as international organisations (IOs), were not deemed to be as important social policies actors as they were in other areas, such as security, environment, or trade, which are policy issues that easily cross borders. Although several IOs that deal with social policies issues have existed for several decades, the actual policy-making and regulation seem to take place

K. Martens $(\bowtie) \cdot D$. Niemann

University of Bremen, Bremen, Germany

e-mail: martensk@uni-bremen.de; dniemann@uni-bremen.de

(C) The Author(s) 2022 
within nation states. Hence, the diffusion of social policies across borders was considered to be less likely, too.

However, IOs have long participated in international life and they have played significant roles in managing cooperation, providing forums for multilateral exchange and disseminating norms. The International Labour Organization (ILO), which celebrated its centennial in 2019, has been dealing with the social question for workers since its inception. Also, the ill-fated League of Nations strongly recommended improvements in social policy areas as a keystone for peaceful coexistence and prosperity. Several contributions in a recent volume (Martens et al. 2021) show that IOs have been significantly shaping discourses about social policy since the Second World War (see for example Yeates and Pillinger 2021 on migrant workers, or Heneghan 2021 on pension policies). With globalisation processes increasing and with domestic borders becoming more and more permeable, national social policies in turn have been affected, opening windows of opportunity for IOs for them to gain significance and influence. It is, however, somewhat surprising that we know little about IOs in the realm of social policy.

In general, scholarly research on IOs has been the domain of International Relations (IR) that regarded IOs as a distinctive form of international institutions (see e.g. Keohane and Nye 1974; Hurd 2011; Barnett and Finnemore 2004; Nielson and Tierney 2003). In general, the study of IOs has advanced significantly in recent decades, and thus, today, we have a far better understanding of different types of global actors, including IOs, and their mechanisms of influence. Research on IOs has examined "why these phenomena exist, how they function and what effects they have on world politics" (Martin and Simmons 2013, 326), while recent research projects have also examined the design of IOs in regard to their assigned authority (Hooghe and Marks 2014, Hooghe et al. 2015; Zürn 2018; Abbott et al. 2014), or studied IOs' performance and policy output (Tallberg et al. 2013, 2014). By now multiple theoretical lenses exist that are applied to studying IOs and their roles in international affairs. Accordingly, the perception of IOs differs from the respective perspective of IR theory, and scholars conceptualise IOs as either "instruments", "arenas", "actors", "bureaucracies" or "resources" (e.g. Hurd 2011; Barkin 2006). 
However, our knowledge about the involvement of IOs varies significantly according to the policy field. Too often, research on IOs focuses on issue areas such as security, economics or environmental policies, while we still know comparatively little about the specific impact of IOs on social policies. Although IOs have been identified as major actors in global social policy (Deacon 2007; Deacon et al. 1997; Kaasch and Martens 2015, Yeates 2008) we need more and deeper research about which IOs are active here, and how they act in the realm of social issues as such. Further research would thus help us to better understand their impact and to assess which changes may be attributed to them. For example, we need to address questions such as which social issues IOs have been promoting actively in global social policy. How do they seek to impact states and other actors? What are their main concerns and goals, and by which mechanisms do they achieve their effects?

Existing research on IOs and social policy has emerged to a large extent from studies on transition and developing countries. For developing countries, different modes for the conditionalities on loans or specific social protection schemes (e.g. Conditional Cash Transfers, CCT) have been identified (for a literature review on CCT, see Ladhari and Sitter 2018). Moreover, we find a variety of contributions focusing on the role of one specific IO in social policy. Such work includes studies on the World Bank (Vetterlein 2007), the ILO (e.g. Deacon 2015) and the OECD (Armingeon and Beyeler 2004). Also specialised UN agencies, such as UNESCO or UNICEF, are well researched in individual case studies (Lerch and Buckner 2018; Holzscheiter 2010). The World Bank, for example, has had a significant impact on social policy development in Central and Eastern Europe as well as in Latin America with regard to the set-up of national pension systems (Orenstein 2003). Also, the OECD considerably impacted the German debate on reforming its education system (Niemann 2010).

However, IOs are not monolithic entities, but rather complex bureaucracies with cooperating but also potentially competing for departments (Barnett and Finnemore 2004). As shown by Seitzer, Niemann, and Martens (2021) the OECD, particularly known in education for its preoccupation with data on secondary schooling with regard to its Programme for International Student Assessment (PISA), has actually been published 
on a much wider range of education issues. It speaks with a diversity of voices since education as a field forms part of various departments and other institutional contexts of the IO. In addition, one and the same IO may appear with different faces in different social policy fields and may transmit multiple messages that play out differently: "(T)he World Bank, for example, can be the good guy (providing support for implementing social policies) or the bad guy (forcing states to introduce certain reforms) depending on what policy field we look at" (Niemann et al. 2021). Recent research efforts on IOs and global social policies have shown that different social policy fields are occupied by multiple IOs that compete and cooperate (Martens et al. 2021). Hence, social policies are a contested area and current research increasingly looks beyond single IOs, instead analysing diverse social policy fields with respect to the IOs involved.

As a matter of fact, IOs use a variety of channels or mechanisms to influence international spheres and national policy-making processes. A few (mainly the internationally operating banks, and regionally or globally operating multi-purpose IOs, such as the EU or the UN) are able to distribute financial resources and implement projects which directly affect people's lives, however, they may also (re)direct national social and education policies as their funds are tied to particular projects and programmes to be implemented according to the IO's vision. Many other IOs active in global social policy rather exert soft governance and act as regionally or globally active think tanks that develop and diffuse ideas and norms about social policy issues. This does not mean that they are toothless tigers, but rather such ideas can be powerful, especially once they are transmitted into national systems, law and policy. Moreover, such IO-induced norms may also become global norms and affect not only the member states of such IOs but all states.

Thus, IOs can be vibrant actors that influence global social governance, and the chapters in this part of the volume shed light on our understanding of IOs and on transnational diffusion processes of social policies. These contributions provide narratives on single IOs, on IOs in a particular field of social policy, and on diffusion processes in which IOs are often a fundamental actor or nodes that tie together relevant stakeholders. The contributors use the term IOs to refer to "public" organisations or intergovernmental organisations (IGOs), in which states are the principal 
members and the term transnational diffusion refers to relational ties between states.

Focusing on education policy as their field of analysis, Fabian BescheTruthe, Helen Seitzer and Michael Windzio study the diffusion of compulsory education in a global perspective. Based on the context of cultural spheres, they argue that countries are tied to each other by sharing cultural characteristics, while they also point out that exposure in terms of close cultural ties to other countries with compulsory education, significantly and substantially increases the rate of adoption.

Jenny Hahs focuses on the expansion of labour legislation towards universalism by tracing in her chapter the adoption of ILO conventions. Her findings generally remind us that even if IOs were "born" in the Global North, they can still unfold considerable importance for states of the Global South.

Dennis Niemann, David Krogmann and Kerstin Martens trace the general development of the IO population in the policy field of education. In fact, since 1945 the number of IOs dealing with education policy has constantly grown, and IOs whose mandates were not originally concerned with education have entered the field, a development that at least potentially could induce competition.

In his chapter on child allowance in Japan, Naho Sugita analyses how the debate on family policy gained influence during the 1960s through the UN's concept of social development. He highlights that the diffusion of social policy ideas by IOs often depends on and is filtered by domestic stakeholders and institutional contexts.

Gabriela de Carvalho and Lorraine Frisina Doetter shed light on the question of whether and how policy ideas from IOs become co-opted in domestic social policy by looking at the case of Columbia and the impact of the World Bank on healthcare reforms.

In her chapter on social health insurance in Albania, Ertila Druga studies how international influences shape domestic public policy. She investigates the influence of the World Bank in the formulation of law in post-communist healthcare reforms in the early 1990s.

With her chapter on Mozambique, Sarah Kassim de Camargo Penteado provides a historical account of the roles of the International Monetary Fund (IMF) and the World Bank in designing, implementing, 
evaluating, measuring and shaping social protection programmes while she also highlights the tension and competition between IOs in developing national political and economic structures.

Irene Dingeldey and Jean-Yves Gerlitz in their chapter on labour market segmentation and the regulation of non-standard employment investigate whether membership in the EU has made a difference. Their analysis focuses on whether its concept of flexicurity becomes translated into national legislation.

In their chapter on pathways to family policy, Tobias Böger, Sonja Drobnič and Johannes Huinink trace how population policies were internationally legitimised, yet implemented through national programmes. The authors examine the three UN conferences on population between 1974 and 1994 to show how population control policies became a global topic by linking it to family policy and reframing it as dependent on the realisation of individual social rights. China and Kenya are examples of contrasting cases with regard to their responses to population questions.

Finally, Heiko Pleines' contribution deals with the IMF and social policy reforms in post-Soviet Russia. While financial collapse forced Russia into an agreement with the IMF in 1998, only six years later it had repaid all debts and was able to pursue its economic policy independently.

Taken together, the chapters in this section show that the relationship between IOs and states in different fields of social policy is complex and multi-layered, in particular, because there is no straightforward answer to the question of how cooperation takes place. It is not always top-down, nor is it always mutually benign. Furthermore, the relationship is multilayered in the sense that at different levels different dynamics can unfold that feedback to the outcome of the IO-state relationship. Furthermore, competition can arise when different IOs are involved. On the national level, political configurations and actor compositions can enable or impede IO influence. Hence, when studying the social policy influences of IOs it has to be kept in mind that the international level almost always exists in tandem with national politics.

Acknowledgements This chapter is a product of the research conducted in the Collaborative Research Centre "Global Dynamics of Social Policy" at the University of Bremen. The centre is funded by the Deutsche 
Forschungsgemeinschaft (DFG, German Research Foundation)—project number 374666841 -SFB 1342.

\section{References}

Abbott, Kenneth W., Philipp Genschel, Duncan Snidal, and Bernhard Zangl. 2014. International Organizations as Orchestrators. Cambridge: Cambridge University Press.

Armingeon, Klaus, and Michelle Beyeler. 2004. The OECD and European Welfare States. Cheltenham: Edward Elgar.

Barkin, J. Samuel. 2006. International Organization: Theories and Institutions. Basingstoke: Palgrave Macmillan.

Barnett, Michael N., and Martha Finnemore. 2004. Rules for the World: International Organizations in Global Politics. Ithaca and London: Cornell University Press.

Deacon, Bob. 2007. Global Social Policy and Governance. London: Sage.

- 2015. The International Labour Organization and Global Social Governance-The 100 Year Search for Social Justice within Capitalism. In Actors and Agency in Global Social Governance, ed. Alexandra Kaasch and Kerstin Martens, 45-63. Oxford: Oxford University Press.

Deacon, Bob, Michelle Hulse, and Paul Stubbs. 1997. Global Social Policy. International Organizations and the Future of Welfare. London: Sage Publications Ltd.

Heneghan, Martin. 2021. International Organizations and the Global Social Governance of Pensions. In In International Organizations in Global Social Governance, ed. Kerstin Martens, Dennis Niemann, and Alexandra Kaasch, 113-135. Cham: Palgrave Macmillan.

Holzscheiter, Anna. 2010. Children's Rights in International Politics: The Transformative Power of Discourse. Basingstoke: Palgrave Macmillan.

Hooghe, Liesbet, and Gary Marks. 2014. Delegation and Pooling in International Organizations. Review of International Organizations 10 (3): 305-328.

Hooghe, Liesbet, Gary Marks, Tobias Lenz, Jeanine Bezuijen, Besir Ceka, and Svet Derderyan. 2015. Scale and Community: The Purpose and Design of International Organizations. Oxford: Oxford University Press.

Hurd, Ian. 2011. International Organizations: Politics, Law and Practice. Cambridge: Cambridge University Press. 
Kaasch, Alexandra, and Kerstin Martens. 2015. Actors and Agency in Global Social Governance. Oxford: Oxford University Press.

Keohane, Robert O., and Joseph S. Nye. 1974. Transgovernmental Relations and International Organizations. World Politics 27 (1): 39-62.

Ladhari, Sheliza, and Kathleen Sitter. 2018. Conditional Cash Transfers: A Critical Review. Development Policy Review 38 (1): 28-41.

Lerch, Julia C., and Elizabeth Buckner. 2018. From Education for Peace to Education in Conflict: Changes in UNESCO Discourse, 1945-2015. Globalisation, Societies and Education 16 (1): 27-48.

Martens, Kerstin, Dennis Niemann, and Alexandra Kaasch. 2021. International Organizations in Global Social Governance. Cham: Palgrave Macmillan.

Martin, Lisa L., and Beth A. Simmons. 2013. International Organizations and Institutions. In Handbook of International Relations, ed. Walter E. Carlsnaes, Thomas Risse, and Beth A. Simmons, 326-351. London: Sage.

Nielson, Daniel L., and Michael J. Tierney. 2003. Delegation to International Organizations: Agency Theory and World Bank Reform. International Organization 57 (2): 241-276.

Niemann, Dennis. 2010. Turn of the Tide-New Horizons in German Education Policymaking through IO Influence. In Transformation of Education Policy, ed. Kerstin Martens, Alexander-Kenneth Nagel, Michael Windzio, and Ansgar Weymann, 77-104. Basingstoke: Palgrave Macmillan. Niemann, Dennis, Kerstin Martens, and Alexandra Kaasch. 2021. The Architecture of Arguments in Global Social Governance: Examining Populations and Discourses of International Organizations in Social Policies. In In International Organizations in Global Social Governance, ed. Kerstin Martens, Dennis Niemann, and Alexandra Kaasch, 3-28. Cham: Palgrave Macmillan.

Orenstein, Mitchell A. 2003. Mapping the Diffusion in Pension Innovation. In Pension Reform in Europe: Process and Progress, ed. Robert Holzmann, Mitchell A. Orenstein, and Michal Rutkowski, 171-193. Washington D.C.: World Bank.

Seitzer, Helen, Dennis Niemann, and Kerstin Martens. 2021. PISA, Publications, and Pathologies: The OECD's Multi-Centric View on Education. Globalisation, Societies and Education 19 (1): 198-212.

Tallberg, Jonas, Thomas Sommerer, Theresa Squatrito, and Christer Jönsson. 2013. The Opening Up of International Organizations: Transnational Access in Global Governance. Cambridge: Cambridge University Press.

- 2014. Explaining the Transnational Design of International Organizations. International Organization 68 (4): 741-774. 
Vetterlein, Antje. 2007. Economic Growth, Poverty Reduction, and the Role of Social Policies: The Evolution of the World Bank's Social Development Approach. Global Governance 13: 513-533.

Yeates, Nicola. 2008. Understanding Global Social Policy. Bristol: Policy Press. Yeates, Nicola, and Jane Pillinger. 2021. International Organizations, Care and Migration: The Case of Migrant Health Care Workers. In In International Organizations in Global Social Governance, ed. Kerstin Martens, Dennis Niemann, and Alexandra Kaasch, 83-111. Cham: Palgrave Macmillan.

Zürn, Michael. 2018. A Theory of Global Governance: Authority, Legitimacy, and Contestation. Oxford: Oxford University Press.

Open Access This chapter is licensed under the terms of the Creative Commons Attribution 4.0 International License (http://creativecommons.org/ licenses/by/4.0/), which permits use, sharing, adaptation, distribution and reproduction in any medium or format, as long as you give appropriate credit to the original author(s) and the source, provide a link to the Creative Commons licence and indicate if changes were made.

The images or other third party material in this chapter are included in the chapter's Creative Commons licence, unless indicated otherwise in a credit line to the material. If material is not included in the chapter's Creative Commons licence and your intended use is not permitted by statutory regulation or exceeds the permitted use, you will need to obtain permission directly from the copyright holder.

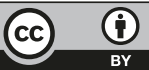

